\title{
Commentary: Functional health status after repair of transposition of the great arteries
}

\author{
Roosevelt Bryant III, MD
}

\footnotetext{
From the Division of Cardiovascular Surgery, The Heart Institute, Cincinnati Children's Hospital Medical Center, Cincinnati, Ohio.

Disclosures: Author has nothing to disclose with regard to commercial support.

Received for publication Aug 15, 2019; revisions received Aug 15, 2019; accepted for publication Aug 19, 2019; available ahead of print Oct 16, 2019.

Address for reprints: Roosevelt Bryant III, MD, Pediatric Heart Transplant Program, Cincinnati Children's Hospital Medical Center, The University of Cincinnati College of Medicine, 3333 Burnet Ave-MLC 2004, Cincinnati, OH 45229 (E-mail: Roosevelt.BryantIII@cchmc.org)

J Thorac Cardiovasc Surg 2020;159:619-20

$0022-5223 / \$ 36.00$

Copyright (c) 2019 by The American Association for Thoracic Surgery

https://doi.org/10.1016/j.jtcvs.2019.08.118
}

The arterial switch operation has become the gold standard for anatomic correction of transposition of the great vessels since the 1980s, when Yacoub, ${ }^{1}$ Castaneda, ${ }^{2}$ and others ${ }^{3}$ showed the procedure could be successfully carried out in neonatal patients. This landmark achievement was born out of decades of surgical and medical innovation, beginning in the 1950s with the first surgical atrial septectomy. Subsequent decades saw novel approaches to improve atrial level mixing with the advent of balloon atrial septostomy ${ }^{4}$ and the development of physiologic surgical repair through the atrial baffle procedures. ${ }^{5,6}$ The culmination of that experience, and the adoption of the neonatal arterial switch operation as the gold standard for anatomic correction of transposition, has led to many congenital cardiac surgery units reporting operative mortality rates less than 7\%. ${ }^{7-9}$ As a result, there has been a shift in how the outcomes of surgical repair of transposition are evaluated, focusing more on long-term morbidity.

In this issue of the Journal, Jegatheeswaran and colleagues $^{10}$ from the Congenital Heart Surgeons Society present a compelling study looking at longitudinal, selfreported, functional health status of patients with transposition of the great vessels who have undergone complete repair. Two features of their analysis distinguish this work from other similar reports in congenital heart disease. First, it follows the same cohort of patients longitudinally and, second, it assesses functional health status as perceived by the patient. However, it includes predominantly patients with less complex forms of transposition. Missing from the analysis, in any meaningful numbers, are patients with significant left ventricular outflow tract obstruction.

Three quality of life surveys were used to assess functional health status. The central finding was that adult patients who had undergone repair of transposition of the great vessels perceived their health to be the same as control patients regardless of the type of repair, ie, atrial baffle procedure or arterial switch operation. These results, as

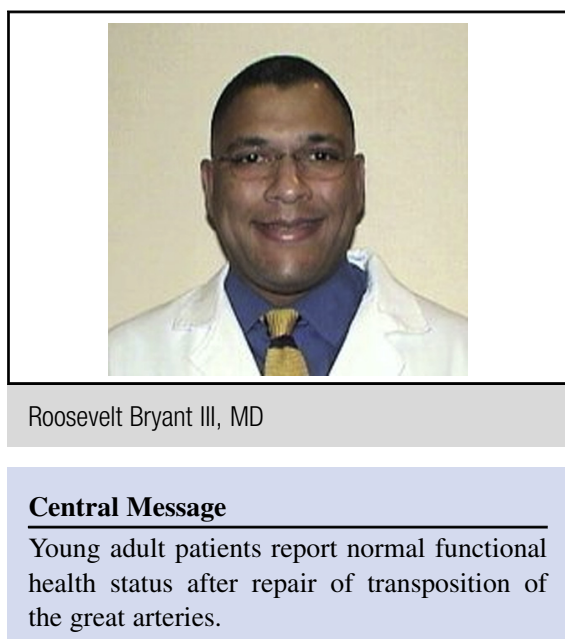

See Article page 604. remarkable as they are, have to be interpreted in the context of important limitations of study. Of the 659 patients known to be alive, there were 210 respondents included in the analysis. It is conceivable that a more robust response rate to the survey might have yielded very different results. In this regard, it is notable that 5 potential respondents to the survey were excluded due to severe cognitive deficits. This fact will hopefully encourage the authors to continue their diligence in understanding the functional health status of the 449 patients who did not respond the questionnaire. It is also difficult to know the impact of the normative data used as a control group for the respondents. Using patients restricted to the northeastern United States and a Dutch cohort as control groups may not create a broad-based population for comparison with the study group. Despite these limitations, the study is a landmark analysis for the specialty. It demonstrates that the innovative efforts of the congenital heart surgery and cardiology community continue to benefit the patients for whom these efforts were made.

\section{References}

1. Radley-Smith R, Yacoub MH. One stage anatomic correction of simple complete transposition of the great arteries in neonates. Br Heart J. 1984;51:685.

2. Castaneda AR, Norwood WI, Jonas RA, Colon SD, Sanders SP, Lang P. Transposition of the great arteries and intact ventricular septum: anatomical repair in the neonate. Ann Thorac Surg. 1984;38:438-43.

3. Quaegebeur JM, Rohmer J, Ottenkamp J, Buis T, Kirklin JW, Blackstone EH, et al. The arterial switch operation. An eight-year experience. J Thorac Cardiovasc Surg. 1986;92:361-84. 
4. Rashkind WJ, Miller WW. Creation of an atrial septal defect without thoracotomy: a palliative approach to complete transposition of the great arteries. JAMA. 1966;196:991-2.

5. Senning A. Surgical correction of transposition of the great vessels. Surgery. 1966;59:334-6.

6. Mustard WT. Successful two-stage correction of transposition of the great vessels. Surgery. 1964;55:469-72.

7. Bove EL, Beekman RH, Snider AR, Rocchini A, Dick M II, Crowley DC, et al Arterial repair for transposition of the great arteries and large ventricular septal defect in early infancy. Circulation. 1988;78:III26-31.
8. Dibardino DJ, Allison AE, Vaughn WK, McKenzie ED, Fraser CD Jr. Current expectations for newborns undergoing the arterial switch operation. Ann Surg. 2004;239:588-96; discussion 596-8.

9. Brawn WJ, Mee RB. Early results for anatomic correction of transposition of the great arteries and for double-outlet right ventricle with subpulmonary ventricular septal defect. J Thorac Cardiovasc Surg. 1988;95:230-8.

10. Jegatheeswaran A, Delvin PJ, DeCampli WM, Welke KF, Williams WG, Blackstone EH, et al. Longitudinal functional health status in young adults with repaired dextro-transposition of the great arteries: a Congenital Heart Surgeons' Society Study. J Thorac Cardiovasc Surg. 2020;159:604-14.e3. 